\title{
Evaluation of Different Extraction Techniques for the Assay of Anti - Acetylcholinesterase Activity of Olive leaves (Olea europaea)
}

\author{
S.S. Khizrieva*(D), S.N. Borisenko, E.V. Maksimenko ${ }^{(D)}$, N.I. Borisenko $(\mathbb{D}$ \\ Research Institute of Physical and Organic Chemistry of the Southern Federal University, \\ 194/2 Stachki Ave., Rostov-on-Don 344090, Russia \\ * Corresponding author: hizrieva@sfedu.ru \\ This article belongs to the regular issue. \\ (C) 2021, The Authors. This article is published in open access form under the terms and conditions of the Creative \\ Commons Attribution (CC BY) license (http://creativecommons.org/licenses/by/4.0/).
}

\section{Abstract}

The total phenol content and the anti-acetylcholinesterase activity were compared in olive leaf (OL) extracts obtained using both subcritical water extraction (SbWE) and conventional solvent extraction (ethanol-water). The method proposed by Ellman (in vitro) was used to study the inhibitory activity of acetylcholinesterase $(A C h E)$. The total content of phenolic compounds and $A C h E$ activities of OL extracts varied depending on the used extraction method. Thus, the extract obtained using the subcritical water technique $\left(220^{\circ} \mathrm{C}\right)$ showed the highest amounts of total phenolic components, expressed as gallic acid equivalents, $(70.4 \mathrm{mg} / \mathrm{g}$ raw material) and the highest inhibitory $A C h E$-activity $\left(\mathrm{IC}_{50}=0.35 \mathrm{mg} / \mathrm{ml}\right)$. The obtained values of the anti- $A C h E$ activity of the extracts of OL demonstrated that the inhibitory activity for SbW-extract $120{ }^{\circ} \mathrm{C}\left(\mathrm{IC}_{50}=2.92 \mathrm{mg} / \mathrm{ml}\right)$ and SbWextract $180{ }^{\circ} \mathrm{C}\left(\mathrm{IC}_{50}=0.8 \mathrm{mg} / \mathrm{ml}\right)$ is higher than that of the traditional extract $\left(\mathrm{IC}_{50}=3.6 \mathrm{mg} / \mathrm{ml}\right)$, respectively. These results indicate a great potential of the subcritical water technique to develop the techniques to produce commercial extracts of OL, and these results could encourage improved utilization of the OL. The collected data on the anti - acetylcholinesterase activity of olive leaves clearly demonstrate the prospects for use of OL extracts in the development of novel pharmaceutical substances and nutraceuticals for the prevention and/or the treatment of Alzheimer's disease as well as some other neurodegenerative diseases.

\section{Keywords}

olive leaves

subcritical water extracts

polyphenols

Alzheimer's disease

anti-Acetylcholinesterase

activity

Ellman's method

Received: 19.05.2021

Revised: 21.09.2021

Accepted: 08.11.2021

Available online: 09.11.2021

\section{Introduction}

Alzheimer's disease (AD) is a neurodegenerative disease that usually affects the elderly. AD is characterized by memory loss, impaired behavior, decreased performance, and slowed-down thinking. At present according to the World Health Organization about 50 million people worldwide are struggle from AD dementia, and over 152 million people may be affected by 2050 globally $[1,2]$.

In recent years, a growing number of works aimed at the finding of new pharmaceutical substances based on secondary plant metabolites [3-6] for the treatment of various neurodegenerative diseases, including $\mathrm{AD}$. One of these promising groups of plant metabolites are polyphe- nols, which are common components of plant raw materials and agricultural wastes.

In the presented work, the medium of subcritical water (in the temperature range from 100 to $220{ }^{\circ} \mathrm{C}$ ) [7] was used to obtain extracts from the leaves of olive (Olea europaea L.) [8] - the most common waste of the olive oil industry.

The antioxidant and neuroprotective effect of plant extracts depends on their qualitative and quantitative composition. The phenolic group is found in the structure of many medicinal plants and substances and largely determines their pharmacological, physicochemical, and chemical properties [9].

Polyphenolic derivatives in OL (Fig. 1) are represented by five main groups of phenolic compounds [10] 
<smiles>OCCc1ccc(O)c(O)c1</smiles>

Hydroxytyrosol, $\mathrm{C}_{8} \mathrm{H}_{10} \mathrm{O}_{3}$

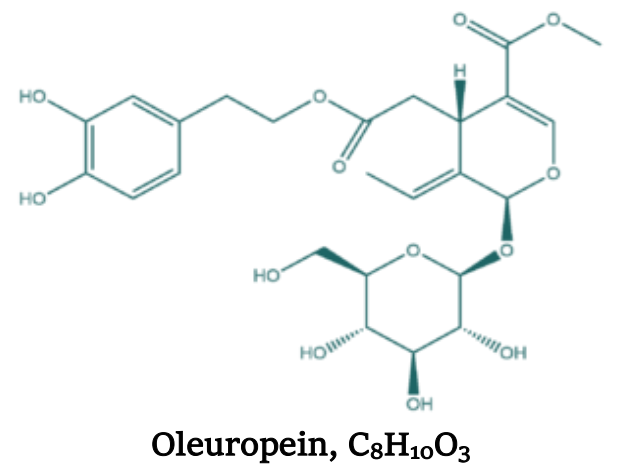

Oleuropein, $\mathrm{C}_{8} \mathrm{H}_{10} \mathrm{O}_{3}$<smiles>O=c1cc(-c2ccc(O)c(O)c2)oc2cc(OC3C(O)C(O)C(O)C(O)C3O)cc(O)c12</smiles>

Luteolin 7-glucoside, $\mathrm{C}_{21} \mathrm{H}_{20} \mathrm{O}_{11}$

4)<smiles>CC(O)C(O)C(O)C(O)C(O)C(O)C(O)C(O)COc1c(-c2ccc(O)c(O)c2)oc2cc(O)cc(O)c2c1=O</smiles>

Rutin, $\mathrm{C}_{27} \mathrm{H}_{30} \mathrm{O}_{16}$
1)<smiles>O=C(O)/C=C/c1ccc(O)c(O)c1</smiles>

Caffeic acid, $\mathrm{C}_{9} \mathrm{H}_{8} \mathrm{O}_{4}$

2)

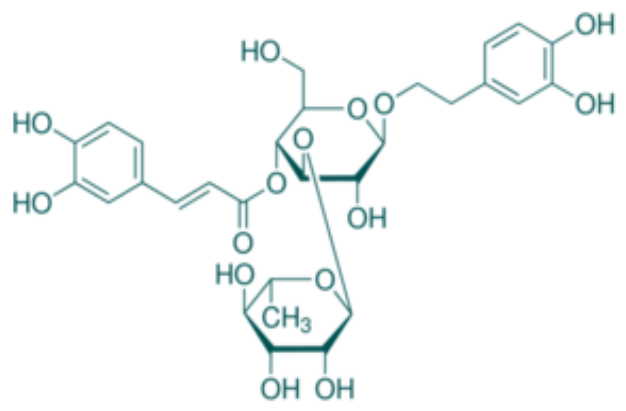

Verbascoside, $\mathrm{C}_{29} \mathrm{H}_{36} \mathrm{O}_{15}$

3)<smiles>O=c1cc(-c2ccc(O)cc2)oc2cc(O[C@@H]3O[C@H](CO)[C@@H](O)[C@H](O)[C@H]3O)cc(O)c12</smiles>

Apigenin 7-glucoside, $\mathrm{C}_{21} \mathrm{H}_{20} \mathrm{O}_{10}$

5)<smiles>Oc1cc(O)c2c(c1)O[C@H](c1ccc(O)c(O)c1)[C@H](O)C2</smiles>

Catechin (flavan-3-ol), $\mathrm{C}_{15} \mathrm{H}_{14} \mathrm{O}_{6}$

Fig. 1 Structural formulas of phenolic compounds in olive leaves (OL): 1 - substituted phenols: tyrosol (2-4-hydroxyphenylethanol), hydroxytyrosol (2-3,4-dihydroxyphenylethanol) and caffeic acid (3,4-dioxycinnamic acid); 2 - oleuroposides (oleuropein and verbascoside); 3 - flavones (luteolin-7-glucoside, apigenin-7-glucoside, diosmethin-7-glucoside, luteolin and diosmetin); 4 - flavonoids (rutin); 5 - flavan-3-ols (catechin)

Olive polyphenols are known to have anticholinesterase activity [11]. Therefore, in this work, the assessment of the sum of polyphenols in OL extracts obtained both by the traditional method and in the medium of subcritical water will be carried out using the Folin-Ciocalteu method [12]. Also, the anti-acetylcholinesterase (anti- $A C h E$ ) activity of the obtained extracts in vitro will be estimated according to the Ellman method [13].

Therefore, the purpose of the present work is the evaluation of different extraction techniques for the assay of anti- $A C h E$ activity, and the determination of total amount of phenolic components of OL extracts obtained using both subcritical water extraction (SbWE) and traditional solvent extraction (TSE).

\section{Experimental}

\subsection{Materials and Method}

Materials. As an object of study, the olive leaves of the $O$. europaea obtained from the Oleaf Company ( Okvel», Russia) were used. Acetylcholinesterase $(A C h E)$ was obtained from Electrophorus electricus (electric eel) (type VI-S, 3.1.1.7, 200-1000 units/mg protein), acetylthiocholine iodide (ATChI) ( $\geq 98 \%$, USA), 5.5'-dithiobis (2-nitrobenzoic) 
acid (DTNB) (99\%, USA), Folin-Ciocalteu reagent (2 M) were supplied by Sigma-Aldrich Company.

Gallic acid (not less than 98\%, MW = 170.12) was purchased from DIA-M Company (Russia). $\mathrm{Na}_{2} \mathrm{CO}_{3}$ (anhydrous, GOST 83-79) and glacial acetic acid $\left(\mathrm{CH}_{3} \mathrm{COOH}\right.$, GOST 61-75, chemically pure: puriss.) were supplied by JSC VEKTON Company (Russia). Hydrochloric acid ( $\mathrm{HCl}$, GOST 14261-77, ultra-high purity: puriss. spec.) was purchased from Sigma Tech Company.

Instrumentation. a SPEKS SSP 705 spectrophotometer (UV-Vid, 190-1100 nm) (manufactured by ZAO Spectroscopic Systems, RF) was used for the measurements.

Methods. In this work the ways for preparation of extracts from leaves of olive (Olea europaea L.) included two different extraction techniques: 1) the traditional solvent (ethanol-water) extraction techniques and 2) the techniques using the medium of subcritical water, as described earlier [8].

The traditional extraction. A 1.0 g sample of the dry olive leaves of $O$. europaea (particle size $0.5-3.0 \mathrm{~mm}$ ) was boiled under reflux with the addition of $15 \mathrm{~mL}$ of $70 \%$ aqueous solution of ethanol for 90 min (bath temperature $82{ }^{\circ} \mathrm{C}$ ). The boiling procedure was repeated 3 times (extraction time $270 \mathrm{~min}$ ). The obtained extracts were filtered, combined, and analyzed by HPLC.

$S B W$-extraction. The treatment of olive leaves in SBW was carried out using a custom-made stainless-steel reactor (autoclave) [8]. The reactor has inner volume of $10 \mathrm{~mL}$ ( $\left.D_{\text {inner }}=12 \mathrm{~mm}\right)$. A portion of ground olive leaves (particle size $0.5-3.0 \mathrm{~mm}$ ) weighing $0.5 \mathrm{~g}$ was placed in a reactor, to which $7 \mathrm{~mL}$ distilled water was then added. The reactor was hermetically sealed and placed in an oven, where it was kept at a certain temperature (accuracy $\pm 1^{\circ} \mathrm{C}$ ) for $1 \mathrm{~h}$. Then the reactor cooled to room temperature ( $15 \mathrm{~min}$ ) in a tank filled with cold water. The contents of the reactor were filtered through a paper filter into a graduated cylinder, washing the reaction mixture with 70\% ethanol until the color was washed out $(\sim V=40 \mathrm{ml}, 60 \mathrm{~min})$. Aliquots of the resulting solutions were dried at room temperature under a fan. Then, the anti-acetylcholinesterase activity of the extracts, as well as the sum of polyphenols and flavonoids in the dry product, were determined using direct and differential spectrophotometry methods.

\subsection{Anti-acetylcholinesterase (anti-AChE) assay}

The activity of $A C h E$ (in vitro) was measured by the modification [11] of Ellman's method [13]. This method measures the activity of $A C h E$ serving acetylcholine as the substrate.

Stock solutions of olive leaf extracts in 50\% ethanol and then diluted to working concentrations with phosphate buffer $(\mathrm{pH}=7.4)$ were prepared.

The $A C h E$ enzyme inhibitory assay was carried out according to Ellman's method [13], as described elsewhere [11], with slight modifications. Olive extracts $(0.6 \mathrm{ml})$ in various concentrations $(0.05-4 \mathrm{mg} / \mathrm{ml})$ were added to the
$1.88 \mathrm{mM}$ ATChI substrate $(0.36 \mathrm{ml})$, followed by addition of $1.44 \mathrm{ml}$ of Ellman's reagent $(0.25 \mathrm{mM})$. Sodium phosphate buffer (0.1 M, pH 7.4) was used for all the preparations and reaction mixture; however, the $A C h E$ enzyme (2 Units $/ \mathrm{mL}$ ) was prepared in sodium phosphate buffer (0.02 M, pH 7.0). After incubation of the reaction mix for $5 \mathrm{~min}$ at room temperature, $A C h E$ enzyme $(0.12 \mathrm{ml}$ ) was added to the reaction mixture. This mixture was stirred ( $5 \mathrm{~s}$ ) and after that the optical density was measured at a wavelength of $412 \mathrm{~nm}$ within 6 minutes from the start of the reaction on a spectrophotometer (UV-Vid, 190-1100 nm).

To exclude the influence of the absorption of extract solutions on the absorption in the reaction mixture control (blank) solutions of the extracts were prepared. That is, the values of its absorption at a wavelength of $412 \mathrm{~nm}$ were subtracted from the values of the absorption of the reaction mixture. Phosphate buffer $(\mathrm{pH} 7.4)$ was added to the control reaction mixture instead of the test substance solution.

The assay was performed in triplicate $(n=3)$. The percentage inhibition was calculated using the formula:

$\%$ inhibition $=1-\left[\frac{\text { Absorption of the test sample at } 412 \mathrm{~nm}}{\text { Absorption control at } 412 \mathrm{~nm}}\right] \times 100$

The results of $A C h E$ inhibition were expressed as $\mathrm{IC}_{50}$ : concentration of extracts $(\mathrm{mg} / \mathrm{mL})$ that resulted in $50 \%$ inhibition of enzyme activity. The values of $\mathrm{IC}_{50}$ were obtained from the dose-response curves.

Total phenolic content assay. Total phenolic content was evaluated spectrophotometrically by the modified Folin-Chocalteu method [12]. The total phenolic contents of the OL were expressed as gallic acid equivalents in milligram per gram of dried leaves. Gallic acid as a polyphenol standard was used. The optical density of the solutions was measured after 30 minutes in a $1 \mathrm{~cm}$ quartz cuvette at a wavelength of $750 \mathrm{~nm}$. Based on the obtained data, a calibration curve was plotted $(y=107.3 x+0.003$, $\left.R^{2}=0.997\right)$. In addition, the total phenolic content was evaluated in the extracts of OL obtained in different ways.

\section{Results and discussion}

As a first stage of this study, the total phenolic content (TPC) of the TSE-extract was determined. It was found that the TSE extract contained $42.6 \mathrm{mg} / \mathrm{g}$ of TPC (in terms of standard gallic acid).

The value of the inhibitory activity of the $A C h E$ enzyme of the TSE extract, based on the dose-response curves, was $\mathrm{IC}_{50}=3.6 \mathrm{mg} / \mathrm{ml}$, respectively.

As a next stage, the set of the SbW-extracts (at $120^{\circ} \mathrm{C}$, $180{ }^{\circ} \mathrm{C}$, and $220{ }^{\circ} \mathrm{C}$ ) were obtained.

Also, the yields of the TPC of the SbW-extracts, obtained in the temperature range $120-220^{\circ} \mathrm{C}$, were determined. The yields of the TPC of SbW-extracts at $120^{\circ} \mathrm{C}$, $180{ }^{\circ} \mathrm{C}$, and $220^{\circ} \mathrm{C}$ were $32.7 \mathrm{mg} / \mathrm{g}, 41.8 \mathrm{mg} / \mathrm{g}$, and 
$70.4 \mathrm{mg} / \mathrm{g}$, respectively (Table 1 ). After that, the values of the $A C h E$-activity for the obtained SbW-extracts were determined. The calculated values of the $A C h E$ activity, expressed as $\mathrm{IC}_{5 \mathrm{O}}$, were: $\mathrm{IC}_{50}=2.92 \mathrm{mg} / \mathrm{ml} \quad\left(12 \mathrm{O}^{\circ} \mathrm{C}\right)$; $\mathrm{IC}_{50}=0.8 \mathrm{mg} / \mathrm{ml} \quad\left(180{ }^{\circ} \mathrm{C}\right) ; \quad \mathrm{IC}_{50}=0.35 \mathrm{mg} / \mathrm{ml} \quad\left(220^{\circ} \mathrm{C}\right)$, respectively. The obtained results are presented in Table 1.

As can be seen from Table 1, the total content of phenolic compounds and $A C h E$ activities of OL extracts varied depending on the used extraction method. The extract obtained using the subcritical water technique $\left(220{ }^{\circ} \mathrm{C}\right)$ showed the highest amounts of total phenolics $(70.4 \mathrm{mg} / \mathrm{g}$ raw material) and the highest $A C h E$ inhibitory activity $\left(\mathrm{IC}_{50}=0.35 \mathrm{mg} / \mathrm{ml}\right)$. Also, the obtained values of the anti$A C h E$ activity of the extracts OL demonstrated that the inhibitory activity for SbW-extract $120^{\circ} \mathrm{C}\left(\mathrm{IC}_{50}=2.92 \mathrm{mg} / \mathrm{ml}\right)$ and SbW-extract $180^{\circ} \mathrm{C}\left(\mathrm{IC}_{50}=0.8 \mathrm{mg} / \mathrm{ml}\right)$ are higher than those observed for the traditional extract $\left(\mathrm{IC}_{50}=3.6 \mathrm{mg} / \mathrm{ml}\right)$, respectively. The obtained results indicated that a percentage (\%) of inhibition of the $A C h E$ enzyme activity by OL extracts is determined by the total content of polyphenols in the investigated extracts.

At the same time, it should be noted that an increase of the temperature of subcritical water from 120 to $220^{\circ} \mathrm{C}$ causes a change in the physicochemical characteristics of water [7, 14]. Therefore, one can expect an increase in the solubility of plant metabolites, on the one hand, and the chemical transformation of polyphenols from the native OL, on the other hand. Recently, the authors have shown that in a subcritical water medium in a temperature range $180-220^{\circ} \mathrm{C}$ a hydrolysis of rutin to quercetin took place (Fig. 2) [14-16].

Table 1 The values $\mathrm{IC}_{50}$ and total phenolic content of OL extracts, obtained by different extraction techniques: the TSE and the SbWE

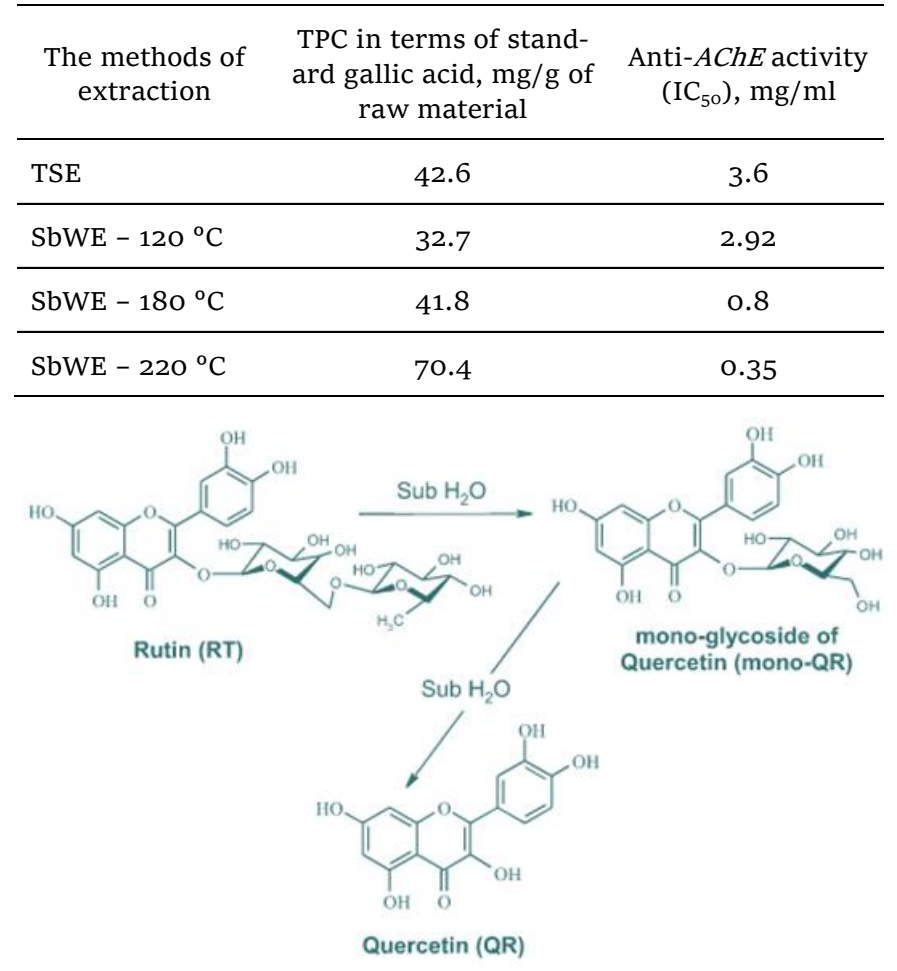

Fig. 2 Hydrolysis of rutin in a medium of subcritical water
According to the literature [17], quercetin is more active against the $A C h E$ enzyme than its glycoside rutin. The latter circumstance suggests that in SBW-extracts (180 and $220^{\circ} \mathrm{C}$ ) the aglycons, such as quercetin, are the main components to determinate the anti-AChE activity of the corresponding extracts.

Thus, it was shown that the solution of the extract obtained in SBW at $220^{\circ} \mathrm{C}$ has the best effect of inhibition of $A C h E$, in contrast to the extract obtained by the traditional method.

\section{Conclusions}

For the first time, the total phenol content and the antiacetylcholinesterase activity were studied in the extracts of olive leaves obtained using both subcritical water and conventional (ethanol-water) extraction.

It was shown that the total content of phenolic compounds and the anti- $A C h E$ activity of OL extracts varies depending on the extraction method used.

The obtained SBW-extract $\left(220{ }^{\circ} \mathrm{C}\right)$ showed the highest amounts of total phenolics, expressed as gallic acid equivalents, (70.4 $\mathrm{mg} / \mathrm{g}$ raw material), and the highest inhibitory $A C h E$-activity $\left(\mathrm{IC}_{50}=0.35 \mathrm{mg} / \mathrm{ml}\right.$ ).

The obtained values of the anti-AChE activity of the extracts of olive's leaves demonstrated that the inhibitory activities for SbWE $120^{\circ} \mathrm{C}\left(\mathrm{IC}_{50}=2.92 \mathrm{mg} / \mathrm{ml}\right)$ and SbWE $180{ }^{\circ} \mathrm{C}\left(\mathrm{IC}_{50}=0.8 \mathrm{mg} / \mathrm{ml}\right)$ are higher than that of the traditional extract $\left(\mathrm{IC}_{5 \mathrm{O}}=3.6 \mathrm{mg} / \mathrm{ml}\right)$, respectively.

The obtained research results demonstrate the prospects for widespread use of the extracts of olive leaves in the development of pharmaceutical substances and nutraceuticals for the prevention or the treatment of Alzheimer's disease, as well as other neurodegenerative diseases.

\section{Acknowledgements}

This work was supported by the Ministry of Science and Higher Education of the Russian Federation (State assignment in the field of scientific activity, project No 0852 2020-0031) and the Russian Foundation for Basic Research (RFBR, grant no. 19-33-90211-Aspiranty (S.S. Khizrieva)).

\section{References}

1. Mahadik VJ, Chavare MN, Patil SS, Wadkar KA. Cognition Enhancing potential of Sesbania grandiflora fruit extract in Scopolamine induced Amnesia in mice. Res J Pharm Technol. 2020;13(11):5057-62. doi:10.5958/0974-360X.2020.00886.0

2. Sharma VK. Current Therapeutic Strategies for Alzheimer's disease: A Lost Direction or A Hope Remains? Res J Pharm Pharmacodynamics. 2010;2(3):215-20. Available from: https://www.researchgate.net/publication/343682407_Curr ent_Therapeutic_Strategies_for_Alzheimer $\% 27 \mathrm{~s}$ disease_A_L ost_Direction_or_A_Hope_Remains

3. Savateev KV, Borisov SS, Voinkov EK, Ulomsky EN, Rusinov VL, Chupakhin ON. 6-Aminotriazolo[1,5-a]pyrimidines as 
precursors of 1,2,4-triazolo[5,1-b]purines. Chimica Techno Acta. 2015;2(2):127-30. doi:10.15826/chimtech.2015.2.2.013

4. Dhinakaran S, Tamilanban T, Chitra V. Targets for Alzheimer's Disease. Res J Pharm Technol. 2019;12(6):3073-77. doi:10.5958/0974-360X.2019.00521.3

5. Kumar DR, Shankar MS, Reddy PP, Kumar B, Sumalatha N. A Review on Alzheimer's Disease. Res J Pharm Pharmacodynamics. 2014;6(1):59-63. Available from:

https://rjppd.org/AbstractView.aspx?PID=2014-6-1-24

6. Srikanth Y, Tamilanban T, Chitra V. Medicinal plants Targeting Alzheimer's disease-A Review. Res J Pharm Technol. 2020;13(7):3454-58. doi:10.5958/0974-360X.2020.00613.7

7. Galkin AA, Lunin VV. Subcritical and supercritical water: a universal medium for chemical reactions. Russ Chem Rev. 2005;74(1):21-35. doi:10.1070/RC2005V074no1ABEHoo1167

8. Maksimenko EV, Khizrieva SS, Borisenko SN, Lekar AV, Borisenko NI, Minkin VI. Subkriticheskaya voda kak instrument dlya polucheniya oleanolovoy kisloty iz list"ev olivy (Olea Europaea L.) Supercrit. fluids: Theory and practice. 2020;15(4):68-73. doi: 10.34984/SCFTP.2020.15.4.006

9. Yaschenko NN, Zhitar SV, Zinovjeva EG. Determination of phenolic compounds in medicinal preparations by galvanostatic coulometry. Chimica Techno Acta. 2021;8(1):20218110. doi:10.15826/chimtech.2021.8.1.10

10. Vogel P, Machado IK, Garavaglia J, Zani VT, de Souza D, Dal Bosco SM. Polyphenols benefits of olive leaf (Olea europaea L) to human health. Nutr. Hosp. 2015;31(3):1427-33. doi: $10.3305 /$ nh.2015.31.3.8400

11. Omar SH, Scott CJ, Hamlin AS, Obied HK. Biophenols: Enzymes ( $\beta$-secretase, Cholinesterases, histone deacetylase and tyrosinase) inhibitors from olive (Olea europaea L.). Fitoterapia. 2018;128:118-29. doi:10.1016/j.fitote.2018.05.011
12. Tutelian VA, Eller KI, Aleshko-Ozhevsky YP. Rukovodstvo po metodam kontrolya kachestva i bezopasnosti biologicheski aktivnykh dobavok k pishche [Guidance on methods for quality control and safety of bioactive food additives]. Moscow: Federal Center for State Sanitary and Epidemiological Supervision of the Ministry of Health of Russia; 2004. 240 p. Russian.

13. Ellman GL, Courtney KD, Andres JrV, Featherstone RM. A new and rapid colorimetric determination of acetylcholinesterase activity. Biochem Pharm. 1961;7(2):88-95. doi:10.1016/0006-2952(61)90145-9

14. Vetrova EV, Maksimenko EV, Khizrieva SS, Bugaeva AF, Borisenko NI, Minkin VI. A simple way for the preparation of natural antioxidant quercetin from rutin by subcritical water. Journal of natural science, biology, and medicine. 2017;8(2):213-215. doi:10.4103/0976-9668.210009

15. Maksimenko EV, Lekar AV, Borisenko SN, Khizrieva SS, Vetrova EV, Borisenko NI, Minkin VI. The development of a one-step method for production of the antioxidant quercetin from flower buds of the Sophora japonica (Sophora japonica L.) in a subcritical water medium. Russ J Phys Chem B. 2018;12(8):1269-75. doi:10.1134/S1990793118080092

16. Maksimenko EV, Lekar AV, Khizrieva SS, Borisenko SN, Vetrova EV, Borisenko NI, Minkin VI. Novel eco-friendly "One-Pot" facile strategy for production of the natural quercetin from the plant: A model study. J Nat Sci Biol Med. 2018;9(2):278-81. doi:10.4103/jnsbm.JNSBM 16117

17. Ademosun AO, Oboh G, Bello F, Ayeni PO. Antioxidative properties and effect of quercetin and its glycosylated form (Rutin) on acetylcholinesterase and butyrylcholinesterase activities. J Evid. Based Complementary Altern. Med. 2016;21(4):NP11-7. doi:10.1177/2156587215610032 